\title{
Palliative Chemotherapy and Targeted Therapy for Recurrent and Metastatic Nasopharyngeal Carcinoma: Reminiscences and the Future
}

\author{
VHF Lee, DLW Kwong
}

Department of Clinical Oncology, Queen Mary Hospital, The University of Hong Kong, Pokfulam, Hong Kong

\begin{abstract}
Nasopharyngeal carcinoma of undifferentiated type is an endemic cancer with a high incidence in Southern China, Taiwan, and Singapore, followed by North African countries and Alaska. Despite intensive definitive treatment, regrettably about 30\% of patients still suffer from loco-regional relapse or even distant metastasis. Palliative chemotherapy has been the standard treatment for those whose disease is not amenable to further radical surgery or a second course of radiotherapy. Though mainly given with palliative intent, this form of chemotherapy can achieve excellent symptom control and prolong survival. More recently targeted therapy has also been widely evaluated in metastatic nasopharyngeal carcinoma. Here we provide a comprehensive review on the use of various types of palliative chemotherapy and targeted therapy for recurrent and metastatic nasopharyngeal carcinoma by searching the MEDLINE and PubMed databases from 1980 to March 2013. The key words used were "nasopharyngeal", "nasopharynx", "recurrent", "metastatic", "chemotherapy", "targeted therapy", and "immunotherapy".
\end{abstract}

Key Words: Antineoplastic agents; Carcinoma; Nasopharyngeal neoplasms; Neoplasm recurrence, local; Radiotherapy, adjuvant

\section{中文摘要}

\section{復發性和轉移性鼻咽癌的姑息性化療和靶向治療：回顧與前膽}

\author{
李浩勳、黇麗雲
}

未分化型鼻咽癌是一種地方性癌症, 在中國南部、台灣和新加坡的發病率偏高, 其次為北非國家 和阿拉斯加。儘管施以針對性強化治療, 仍然有約 $30 \%$ 的患者遭受癌症局部復發甚至遠處轉移的 痛苦。對於那些不適合接受擴大根治性手術或第二療程放療的患者來説, 姑息性化療一向是標 準的治療方法。雖然該形式的化療主要以姑息緩解為目的, 卻可達到出色的症狀控制並延長生 存期。最近, 以靶向治療醫治轉移性鼻咽癌被廣泛評估。我們檢索MEDLINE和PubMed數據庫中 1980年至2013年3月的相關文獻, 全面回顧復發性和轉移性鼻咽癌的各種類型姑息性化療和靶向 治療的運用。使用的關鍵字為「鼻咽癌」（nasopharyngeal），「鼻咽部」（nasopharynx），「復 發」（recurrent），「轉移」（metastatic），「化療」（ chemotherapy），「靶向治療」（targeted therapy ) 和「免疫治療」（immunotherapy）

Correspondence: Dr VHF Lee, Department of Clinical Oncology, Queen Mary Hospital, The University of Hong Kong, Pokfulam, Hong Kong.

Tel: (852) 2255 4222; Fax: (852) 2255 4609; Email:vhflee@hku.hk

Submitted: 29 Apr 2013; Accepted: 3 Jul 2013. 


\section{INTRODUCTION}

Undifferentiated nasopharyngeal carcinoma (NPC) is an endemic cancer with a high incidence in Southern China, Taiwan, and Singapore, and a lower incidence in North African countries and Alaska. Radiotherapy is the mainstay of treatment for early stage NPC, while concurrent chemoradiation is indicated for locoregionally advanced disease, as revealed by previous phase III randomised controlled trials and a recent meta-analysis. ${ }^{1}$ Nevertheless, about $30 \%$ of cases relapse locoregionally or distantly, despite intensive definitive treatment. ${ }^{2}$ Though most of these relapsed patients have an unfavourable survival outcome, their survival can be significantly prolonged with palliative chemotherapy and more recently targeted therapy has demonstrated encouraging objective responses and treatment outcomes. In this article, we comprehensively review the previous literature on the use of palliative chemotherapy and comment on the use of targeted therapy and other novel future treatments for recurrent and metastatic NPC.

\section{METHODS}

MEDLINE and PubMed databases were searched from 1980 till March 2013. Key words including "nasopharyngeal", "nasopharynx", "recurrent", "metastatic", "chemotherapy", "targeted therapy", and "immunotherapy" were used for the literature search.

\section{PALLIATIVE CHEMOTHERAPY}

Although well established as a standard treatment for metastatic NPC, there have been no randomised trials comparing efficacy of different chemotherapeutic regimens and no evidence pertaining to prolongation of survival compared to best supportive care. ${ }^{3}$ Apart from that, quality-of-life assessment during chemotherapy is often ignored in these retrospective or phase II studies. Moreover, the majority are smallscale studies that are inherently difficult for the purpose of meaningful comparison between different chemotherapy regimens. In summary, these trials can be categorised into monotherapy, doublet chemotherapy, and polychemotherapy studies used in chemo-naïve patients or those who have received prior chemotherapy for recurrent / metastatic disease.

\section{Monotherapy}

Anecdotal reports have demonstrated that the use of older agents like methotrexate, bleomycin, 5-fluorouracil (5-FU), epidoxorubicin, mitoxantrone, and platinum compounds produce a response rate between 15 and $30 \% .^{3-5}$ More recent clinical trials have investigated the efficacy of newer agents including gemcitabine, irinotecan, paclitaxel, capecitabine, and docetaxel (Table 1) ${ }^{5-14}$ Notably, gemcitabine and capecitabine are the foci of recent studies, offering a response rate between 24 and $48 \%$ and median progression-free survival (PFS) between 4 and 14 months. ${ }^{8-13}$ Docetaxel, as a single agent, also produced a response rate of $37 \%$ and a median PFS of 5 months. ${ }^{14}$

\section{Doublet Chemotherapy}

Platinum doublets are regarded as the principal treatment modality for medically fit patients with metastatic NPC. Clinical trials entailing platinum doublets have exhibited response rates from 20 to

Table 1. Monochemotherapy in recurrent and / or metastatic nasopharyngeal carcinoma with or without pretreatment.

\begin{tabular}{|c|c|c|c|c|c|c|c|}
\hline Author(s) & Study & No. of patients & Regimen & $\begin{array}{l}\text { OR rate } \\
(\%)\end{array}$ & $\begin{array}{l}\text { CR rate } \\
(\%)\end{array}$ & Median PFS & Median OS \\
\hline Dugan et $\mathrm{al}^{5}$ & $\mathrm{Ph} \|$ & $108 \mathrm{R}+\mathrm{M}$ pretreated & Mitoxantrone & 25 & NR & 4.5 months & 13 months \\
\hline Au et $\mathrm{al}^{6}$ & $\mathrm{Ph} \|$ & $24 \mathrm{M}$ untreated & Paclitaxel & 21.7 & 0 & 7.5 months & 12 months \\
\hline Poon et $\mathrm{al}^{7}$ & $\mathrm{Ph} \|$ & $28 \mathrm{M}$ pretreated & Irinotecan & 14 & 0 & 3.9 months & 11.4 months \\
\hline \multirow[t]{2}{*}{ Foo et $a^{8}$} & $\mathrm{Ph} \|$ & $25 \mathrm{M}$ pretreated & Gemcitabine & 28 & 4 & 3.6 months & 7.2 months \\
\hline & & $27 \mathrm{M}$ untreated & & 48 & 3.7 & 5.1 months & 10.5 months \\
\hline Ma et $\mathrm{al}^{9}$ & Retrospective & $\begin{array}{l}18 \mathrm{R}+\mathrm{M} \text { untreated } \\
\text { and pretreated }\end{array}$ & Gemcitabine & 34 & 6 & $31 \%$ (1 month) & $48 \%$ (1 year) \\
\hline Chua et $\mathrm{al}^{10}$ & $\mathrm{Ph} \|$ & $17 \mathrm{R}+\mathrm{M}$ pretreated & Capecitabine & 23.5 & 5.9 & 4.9 months & 7.6 months \\
\hline Chua et al ${ }^{11}$ & Retrospective & $49 \mathrm{R}+\mathrm{M}$ pretreated & Capecitabine & 37 & 6 & 5 months & $\begin{array}{l}14 \text { months; } \\
54 \% \text { (1 year) }\end{array}$ \\
\hline Ciuleanu et al ${ }^{12}$ & $\mathrm{Ph} \|$ & $26 \mathrm{R}+\mathrm{M}$ pretreated & Capecitabine & 48 & 9 & 14 months & $62 \%$ (1 year) \\
\hline Zhang et $\mathrm{al}^{13}$ & Ph II & 32 pretreated & Gemcitabine & 43.8 & 0 & 5.1 months & $\begin{array}{l}16 \text { months; } \\
63 \% \text { (1 year) }\end{array}$ \\
\hline Ngeow et al ${ }^{14}$ & $\mathrm{Ph} \|$ & $30 \mathrm{R}+\mathrm{M}$ pretreated & Docetaxel (weekly) & 37 & 0 & 5.3 months & 12.8 months \\
\hline
\end{tabular}

Abbreviations: $\mathrm{CR}$ = complete response; $\mathrm{M}=$ metastatic; $\mathrm{NR}=$ not reported; $\mathrm{OR}$ = objective response; OS = overall survival;

$\mathrm{PFS}=$ progression-free survival; $\mathrm{Ph} \|$ = phase $\| ; \mathrm{R}=$ recurrent. 
$76 \%$; one study showed that all patients with recurrent disease only responded to cisplatin and 5-FU (Table 2). ${ }^{9,15-36}$ Platinum and 5-FU combination therapy is the most popular among doublet regimens widely practised in Asian countries where the disease is endemic. The dose of cisplatin is $100 \mathrm{mg} / \mathrm{m}^{2}$ on day 1 and that for 5 -FU is $1000 \mathrm{mg} / \mathrm{m}^{2}$ over 3 to 5 days, given every 3 weeks. This popular regimen produced an overall response (OR) rate between 66 and $78 \%$ and a median survival of 12 to 14 months. ${ }^{15-17}$ In particular, Chi et a ${ }^{17}$ revealed that all patients with locally recurrent disease responded to cisplatin, 5-FU and leucovorin producing a median survival of 34 months, while $80 \%$ of those with metastatic disease responded with a median survival of 14 months. This regimen was found effective even in patients who had received prior chemotherapy. All five patients who had earlier received mitoxantrone still responded, suggesting a lack of crossresistance. Another four patients with good responses to prior induction chemotherapy with cisplatin and 5-FU followed by radiotherapy who then developed metastatic disease with disease-free intervals greater than 1 year still, nevertheless, responded to the same regimen..$^{17}$ Moreover, the toxicity profile is generally favourable with mild immunosuppression and peripheral neuropathy. However cisplatin-induced nephrotoxicity and ototoxicity were of concern, especially in patients who had also received cisplatin during their previous definitive chemoradiation. Commonly, carboplatin has been used as a substitute of cisplatin for advanced head and neck cancers including NPC. ${ }^{37}$ Two older randomised controlled studies on advanced head and neck cancers demonstrated that cisplatin was superior to carboplatin in terms of improved response rate..$^{38,39}$ One of these showed cisplatin conferred superior diseasefree survival and overall survival (OS) compared to carboplatin when both were used with 5-FU. ${ }^{39}$ However this study did not recruit patients with recurrent or metastatic diseases. More recently, carboplatin has been tested with concurrent chemoradiation against cisplatinbased concurrent chemoradiation in a randomised controlled non-inferiority study..$^{40}$ Patients with locally advanced NPC were randomised to receive cisplatin chemoradiation versus carboplatin chemoradiation followed by adjuvant chemotherapy using the same platinum compound as in the concurrent phase coupled with 5-FU. No difference in 3-year disease-free survival $(p=0.9613)$ and OS $(p=0.9814)$ was demonstrated.

Table 2. Doublet chemotherapy regimens in recurrent and / or metastatic nasopharyngeal carcinoma with or without pretreatment.

\begin{tabular}{|c|c|c|c|c|c|c|c|}
\hline Author(s) & Study & $\begin{array}{l}\text { No. of } \\
\text { patients }\end{array}$ & Regimens & $\begin{array}{c}\text { OR rate } \\
(\%)\end{array}$ & $\begin{array}{c}\text { CR rate } \\
(\%)\end{array}$ & Median PFS & Median OS \\
\hline Wang and $\operatorname{Tan}^{15}$ & Retrospective & $25 \mathrm{M}$ & Cisp + 5-FU & 76 & 8 & NR & NR \\
\hline Au and $\mathrm{Ang}^{16}$ & $\mathrm{Ph} \|$ & $24 R+M$ & Cisp + 5-FU & 66 & 13 & 8 months & 11 months \\
\hline \multirow[t]{2}{*}{ Chi et $\mathrm{al}^{17}$} & $\mathrm{Ph} \|$ & $20 R$ & Cisp + 5-FU / LV & 100 & 15 & NR & 34 months \\
\hline & & $15 \mathrm{M}$ & & 80 & 13 & NR & 14 months \\
\hline Stein et $\mathrm{al}^{18}$ & $\mathrm{Ph} \|$ & $18 R+M$ & Cisp + Ifos & 59 & 15 & $N R$ & $\mathrm{NR}$ \\
\hline Yeo et al ${ }^{19}$ & $\mathrm{Ph} \|$ & $42 \mathrm{M}$ & Carbo + 5-FU & 38 & 17 & NR & 12.1 months \\
\hline Yeo et $\mathrm{al}^{20}$ & $\mathrm{Ph} \|$ & $27 R+M$ & Carbo + Pac & 59 & 11 & 6 months & 13.9 months \\
\hline Tan et $\mathrm{al}^{21}$ & $\mathrm{Ph} \|$ & $32 \mathrm{M}$ & Carbo + Pac & 75 & 3 & 7 months & 12 months \\
\hline Ciuleanu et $\mathrm{al}^{22}$ & $\mathrm{Ph} \|$ & $40 \mathrm{M}$ & Carbo + Pac & 27.5 & 7.5 & 3.5 months & 11.5 months \\
\hline Ngan et $\mathrm{al}^{23}$ & Ph II & $44 R+M$ & Cisp + Gem & 73 & 20 & 10.6 months & 15 months \\
\hline Ma et $\mathrm{al}^{9}$ & $\mathrm{Ph} \|$ & $14 R+M$ & Cisp + Gem & 64 & 14 & $13 \%$ (1 year) & $68 \%$ (1 year) \\
\hline Wang et $\mathrm{al}^{24}$ & Retrospective & $75 R+M$ & Cisp + Gem & 42.7 & 5.3 & 5.6 months & 9 months \\
\hline Ma et $\mathrm{al}^{25}$ & Ph II & $40 R+M$ & Oxali + Gem & 56.1 & 0 & 9 months & 19.6 months \\
\hline McCarthy et $\mathrm{al}^{26}$ & $\mathrm{Ph} \|$ & $9 R+M$ & Cisp + Doc & 22 & 0 & 8.4 months & $76 \%$ (1 year) \\
\hline Chua et $\mathrm{al}^{27}$ & $\mathrm{Ph} \|$ & $19 M$ & Cisp + Doc & 62.5 & 6.3 & 5.6 months & 12.4 months \\
\hline Li et al28 & $\mathrm{Ph} \|$ & $48 \mathrm{M}$ & Cisp + Cape & 62.5 & 6.3 & 7.7 months & 13.3 months \\
\hline Chua et $\mathrm{al}^{29}$ & $\mathrm{Ph} \|$ & $18 R+M$ & Ifos + 5-FU / LV & 56 & 6 & 6.5 months & $51 \%$ (1 year) \\
\hline Huang et $\mathrm{al}^{30}$ & $\mathrm{Ph} \|$ & $34 R+M$ & Ifos + Doc & 67.6 & 14.7 & 6 months & NR \\
\hline Altundag et $\mathrm{al}^{31}$ & Ph II & $21 R+M$ & Ifos + Doc & 33.3 & 0 & 7 months & NR \\
\hline Wang et $\mathrm{al}^{32}$ & $\mathrm{Ph} \|$ & $39 \mathrm{M}$ & Gem + Vino & 36 & 3 & 5.6 months & 11.9 months \\
\hline Dede et $\mathrm{al}^{33}$ & Retrospective & $30 R+M$ & Ifos + Doxo & 30 & 0 & 4 months (median TTP) & NR \\
\hline Chen et $\mathrm{al}^{34}$ & $\mathrm{Ph} \|$ & $61 R+M$ & Gem + Vino & 37.7 & 1.6 & 5.2 months & 14.1 months \\
\hline Yau et $a^{35}$ & $\mathrm{Ph} \|$ & $15 R+M$ & Cisp + Pem & 20 & 7 & 30 weeks (median TTP) & NR \\
\hline Chua et $\mathrm{al}^{36}$ & $\mathrm{Ph} \|$ & $44 \mathrm{M}$ & Cisp + Cape & 53.8 & 2.6 & 7.3 months (median TTP) & 28.0 months \\
\hline
\end{tabular}

Abbreviations: Cape = capecitabine; Carbo = carboplatin; Cisp = cisplatin; $\mathrm{CR}=$ complete response; Doc = docetaxel; Doxo = doxorubicin; 5-FU = 5-fluorouracil; Gem = gemcitabine; Ifos = ifosphamide; $L V$ = leucovorin; $M$ = metastatic; $N R$ = not reported; OR = objective response; OS = overall survival; Oxali = oxaliplatin; Pac = paclitaxel; Pem = pemetrexed; PFS = progression-free survival; Ph $\|=$ phase $\| ; R=$ recurrent; TTP = time to progression; Vino = vinorelbine. 
In 2013, a retrospective Malaysian study compared cisplatin and 5-FU with carboplatin and 5-FU in 41 patients with recurrent and metastatic squamous-cell head and neck cancer and NPC. ${ }^{41}$ This showed that carboplatin and 5-FU (median survival, 12 months) was not inferior to cisplatin and 5-FU (median survival, 10 months; $p=0.110$ ). However, drawbacks of this study were that no subgroup analysis was performed for NPC patients only and there were six treatment-related mortalities $(14.6 \%)-$ four in the carboplatin $+5-\mathrm{FU}$ group and two in the cisplatin + 5-FU group.

Other active agents for recurrent and metastatic NPC include gemcitabine, capecitabine, oxaliplatin and taxanes. ${ }^{42}$ One study published in 2002 tested gemcitabine with platinum as first-line chemotherapy for metastatic NPC in 44 patients and was carried out in Hong Kong. ${ }^{23}$ It showed an OR rate of $73 \%$ and a median PFS of 11 months. Gemcitabine together with oxaliplatin (a third-generation platinum compound) was also evaluated. This Hong Kong multicentre study found that first-line gemcitabine and oxaliplatin produced an OR of $57 \%$ and a median PFS of 9 months. ${ }^{25}$ Use of gemcitabine with a non-platinum compound in NPC patients pretreated with platinum was also found to be feasible. A Chinese study including patients all with disease progression while still on previous platinumbased chemotherapy demonstrated an OR rate of $36 \%$ and median PFS of 6 months after gemcitabine and vinorelbine. ${ }^{32}$ Another Chinese study, in which about $15 \%$ of 61 patients had disease progression while still on platinum-based chemotherapy, demonstrated an OR rate of 38\%, and a median PFS of 5 months; and the median OS being 14 months following treatment with a median of 4 cycles of gemcitabine and vinorelbine. ${ }^{34}$ Use of capecitabine, an oral pro-drug of 5-FU, in combination with cisplatin as first-line treatment was also evaluated. Chua et $\mathrm{al}^{36}$ published a multicentre study on such treatment in 44 patients with previously untreated metastatic NPC. Of the 39 patients evaluable for efficacy, the OR rate was $54 \%$ including one patient (3\%) showing a complete response. The median time to progression was 7 months and the median OS was 28 months. In addition, this study specially emphasised quality-of-life assessment using FACT-G and diseasespecific FACT-H\&N questionnaires. ${ }^{36}$ These authors described mild decline in quality-of-life scores after chemotherapy, which was likely due to side-effects and hospitalisation. Docetaxel and ifosphamide doublet chemotherapy regimens were also extensively studied. ${ }^{27,28,30,31}$ When used with platinum or non- platinum compounds, OR rates were between 22 and $68 \%$ and median PFS ranged between 6 and 8 months.

Most recently a Hong Kong study investigated the role of pemetrexed (a multi-targeted 5-FU analogue) when combined with cisplatin for patients with recurrent or metastatic NPC. ${ }^{35}$ When used with regular folic acid and vitamin B12 supplements, pemetrexed per se has very limited treatment-related side-effects. Fifteen patients were recruited into this study, six of whom had locoregional recurrence while the rest had distant metastases with or without locoregional recurrence. Three patients were previously treated with cisplatinbased chemotherapy as prior first-line therapy, while the rest received cisplatin during their initial definitive chemoradiation. Serum biochemistry for Epstein-Barr virus (EBV-DNA) was also monitored as a surrogate tumour marker. The OR rate was $20 \%$ and one patient (7\%) enjoyed complete remission. Another eight patients $(53 \%)$ had their disease stabilised, giving an overall clinical benefit rate of $73 \%$; three patients (21\%) had undetectable EBV-DNA after treatment. Pemetrexed was well-tolerated; only one patient who had grade 4 anaemia. The most common grade 3 toxicities included neutropenia (27\%) and anaemia $(20 \%)$. No patient developed febrile neutropenia after treatment. As persistent and irreversible treatmentrelated toxicity often precludes long-term use of chemotherapy, it is hoped that combination regimens with such new agents can offer durable disease control and at the same time minimise toxicities.

It is still under hot debate whether patients can be safely re-challenged with cisplatin if they were exposed to it during previous induction chemotherapy, definitive cisplatin-based chemoradiation or prior palliative chemotherapy. An older study revealed that all four patients with a disease-free interval of more than 1 year after induction cisplatin and 5-FU and radiotherapy still responded to the same regimen. ${ }^{17}$ In their study on doublet regimen using cisplatin and capecitabine for previously untreated metastatic NPC, Chua et $\mathrm{al}^{36}$ demonstrated that prior adjunctive (neoadjuvant, concurrent, or adjuvant) chemotherapy given at least 6 months before study entry had a longer PFS (9 vs. 7 months) and OS (30 vs. 28 months), though the differences were not statistically significant. Recently, molecular medicine has played an important role in the prediction of chemosensitivity. Some light has been shed on the discovery of excision repair cross complementation group 1 (ERCC1) and xeroderma 
pigmentosum complementation group $\mathrm{F}(\mathrm{XPF})$ involved in the repair cisplatin-DNA adducts via different pathways. These have a bearing on the nucleotide excision repair pathway, double-strand break repair, and repair of interstrand crosslinks. ${ }^{43-48}$ When associated with ERCC1, XPF forms a heterodimer which functions as a structure-specific endonuclease. The ERCC 1 also binds and stabilises XPF, which enhances the latter's endonuclease to create an incision 5' to the DNA lesion, thus allowing DNA to be repaired. Four studies confirmed that high expression levels of ERCC1 conferred poor treatment outcomes in NPC when cisplatin was administered as induction treatment, concurrently with radiation therapy or palliative setting. ${ }^{43-46}$ Another study showed that high ERCC1 levels predicted poor locoregional control, but did not predict resistance to cisplatin. ${ }^{47}$ One more recent study showed that neither ERCC1 nor XPF predicted locoregional recurrence, disease-free survival and OS in 142 patients with NPC treated with curative intent. ${ }^{48}$ Perhaps one of the solutions to these conflicting results is to re-biopsy the recurrent / metastatic lesions to evaluate chemosensitivity to platinum.

Overall, all these published trials should be interpreted with great caution, due to small sample sizes, the nature of phase II studies, patient population heterogeneity (locoregional recurrence alone vs. distant metastasis), and variations in prior lines of systemic chemotherapy (especially if platinum-based). Notwithstanding the limitations of these clinical and molecular studies, we recommend cisplatin, preferably with 5-FU, as the first choice due to the long history and experience with these agents, especially for chemo-naïve patients. When length of hospital stay becomes an issue, 5-FU may be substituted by newer agents such as capecitabine, gemcitabine, and taxanes. For second-line or subsequent treatment of metastasis, whether platinum-based chemotherapy was given previously is a consideration. For patients treated with platinum-based chemotherapy, subsequent treatment depends on performance status, toxicity, and the interval to recurrence after previous platinum-based regimen. Re-challenge with cisplatin and 5-FU can be considered in patients who enjoyed a good initial response to the same regimen with an intervening disease-free period of more than 1 year. Carboplatin is an acceptable substitute producing similar responses and outcomes when cisplatin is contraindicated, though it generally gives rise to more haematological toxicities. For patients who fail platinum and 5-FU or whose disease relapse within a year of such a regimen, second-line treatment including gemcitabine, capecitabine, or taxanes with or without platinum can be considered.

\section{Polychemotherapy}

Use of more than doublet combination chemotherapy has not been shown to be superior to doublet counterparts. Several trials reported on the polychemotherapy for recurrent NPC and demonstrated encouraging response rates but also more treatment-related toxicities (Table 3). ${ }^{49-56}$ More importantly, they have not been compared with the standard 5-FU + cisplatin doublet regimen. One study, CAPABLE, incorporating five compound (cisplatin, methotrexate, bleomycin, cyclophosphamide, and doxorubicin), was associated with a response rate of $80 \%$ but also an extraordinarily high treatment-related mortality of $12 \% .{ }^{52}$ Another phase II study, using 5-FU, mitomycin, epirubicin, and cisplatin demonstrated a response rate of $52 \%$ at the expense of iatrogenic death of $9 \% .^{54}$ In general, polychemotherapy entailing three or more agents is not routinely recommended.

Table 3. Results for polychemotherapy in recurrent and / or metastatic nasopharyngeal carcinoma with or without pretreatment.

\begin{tabular}{|c|c|c|c|c|c|c|c|}
\hline Author(s) & Study & No. of patients & Regimens & OR (\%) & $\mathrm{CR}(\%)$ & Median PFS & Median OS \\
\hline Boussen et al ${ }^{49}$ & $\mathrm{Ph} \|$ & $\begin{array}{l}49 \mathrm{R}+\mathrm{M} \text { untreated and } \\
\text { pretreated }\end{array}$ & Cisp + B + 5-FU & 79 & 19 & 50 months & NR \\
\hline Su et $a^{50}$ & Ph II & $25 R+M$ & $\mathrm{Cisp}+\mathrm{B}+5-\mathrm{FU}$ & 40 & 3 & NR & NR \\
\hline Azli et $\mathrm{al}^{51}$ & $\mathrm{Ph} \|$ & $44 \mathrm{R}+\mathrm{M}$ pretreated and not & BEC (B + Epi + Cisp) & 45 & 20 & 53 months & NR \\
\hline Siu et $\mathrm{a}^{52}$ & $\mathrm{Ph} \mathrm{I} / \|$ & $\begin{array}{l}17 \mathrm{R} \\
44 \mathrm{M}\end{array}$ & CAPABLE & $\begin{array}{l}41 \\
80\end{array}$ & $\begin{array}{r}23.5 \\
6.8\end{array}$ & $\begin{array}{l}\text { NR } \\
\text { NR }\end{array}$ & $\begin{array}{l}16 \text { months } \\
14 \text { months }\end{array}$ \\
\hline Taamma et $a^{53}$ & $\mathrm{Ph} \|$ & $23 R+M$ & FBEC (5-FU + B + Epi + Cisp) & 78 & 39 & 42 months & NR \\
\hline Hasbini et $a^{54}$ & $\mathrm{Ph} \|$ & $44 R+M$ & $\begin{array}{l}\text { FMEP (5-FU + mitomycin + Epi } \\
+ \text { Cisp) }\end{array}$ & 52 & 13 & 9 months & 14 months \\
\hline Leong et al ${ }^{55}$ & $\mathrm{Ph} \|$ & $28 \mathrm{M}$ & Carbo + Gem + Pac + 5-FU / LV & 86 & 11 & 8 months & 22 months \\
\hline Huang et $\mathrm{al}^{56}$ & $\mathrm{Ph} \|$ & $56 R+M$ & $\mathrm{DCF}(\mathrm{Doc}+\mathrm{Cisp}+5-\mathrm{FU})$ & 72.5 & 9.8 & NR & NR \\
\hline
\end{tabular}

Abbreviations: B = bleomycin; CAPABLE: Cyclophospamide + Bleomycin + Doxorubicin + Cisplatin; Carbo = carboplatin; Cisp = cisplatin; CR = complete response; $\mathrm{Doc}=$ docetaxel; Epi = epirubicin; 5-FU = 5-fluorouracil; Gem = gemcitabine; lfos = ifosphamide; LV = leucovorin; $\mathrm{M}=$ metastatic; NR = not reported; OR = objective response; OS = overall survival; Pac = paclitaxel; PFS = progression-free survival; Ph II = phase $\| ; R=$ recurrent. 


\section{PALLIATIVE TARGETED THERAPY}

A number of studies have tested the efficacy of targeted therapy for metastatic NPC. First of all, like other squamous-cell head and neck cancers, epidermal growth factor receptor (EGFR) is also highly expressed in NPC. ${ }^{57-59}$ Thus, a few studies investigated the role of EGFR tyrosine kinase inhibitors and monoclonal antibodies in metastatic NPC. A small phase II study from Hong Kong showed that none of 19 patients responded after gefitinib in previously heavily pretreated NPC, with median values for time to progression and OS of 4 and 16 months, respectively. ${ }^{60}$ Another Hong Kong study was terminated due to lack of efficacy following treatment with gefitinib. ${ }^{61}$ Likewise, a phase II study, using erlotinib as maintenance treatment after 6 cycles of gemcitabine and cisplatin in chemo-naïve patients with metastatic NPC, revealed stable disease in only three out of 12 evaluable patients. ${ }^{62}$ Thus, erlotinib appeared to be no better than geftinib in metastatic NPC. Use of cetuximab, a monoclonal antibody against EGFR, in combination with carboplatin was also tested. Seven (12\%) out of 59 patients enjoyed a partial response with a median PFS of 3 months and median OS of 8 months, but at the expense of significant toxicity (grade $\geq 3$ toxicities in $52 \%$ of the patients). ${ }^{63}$

Vascular endothelial growth factor (VEGF) and its receptor (VEGFR) is also a potential target of treatment in NPC. Its overexpression was found in 60 to $67 \%$ of patients and also conferred a shorter survival. ${ }^{64,65}$ The use of sorafenib, an oral multikinase inhibitor, was also not shown to be more efficacious than systemic chemotherapy. ${ }^{66} \mathrm{~A}$ more recently published phase II study on sorafenib in combination with standard cisplatin and 5-FU regimen in the induction phase followed by maintenance sorafenib until disease progression demonstrated a high response rate of $78 \%$ and median PFS of 7 months and median OS of 12 months ${ }^{67}$ However, this regimen was also accompanied by a high frequency of hand-foot-skin reactions $(83 \%$ in all and $19 \%$ in grade $\geq 3$ ), leucopenia ( $78 \%$ in all and $7 \%$ in grade $\geq 3$ ), and haemorrhagic events (22\% in all and $2 \%$ in grade $\geq 3$ ). Another multikinase tyrosine kinase inhibitor sunitinib was also tested in metastatic NPC in Hong Kong. ${ }^{68}$ Of the 10 patients who had posttreatment radiological assessment for tumour response, one patient had a partial response and another three remained stable for at least 12 months. Meanwhile, the haemorrhagic events also deserve attention (64\% in all, $29 \%$ in grade $3 / 4$, and $14 \%$ in grade 5) and included epistaxis, haemoptysis, and haematemesis in 6,3 , and
2 patients, respectively. Two patients with tumour invasion to the carotid sheath suffered a fatal epistaxis / haematemesis which was likely secondary to carotid blowout after tumour shrinkage. Pazopanib, another orally available multikinase inhibitor against VEGFR-1, -2 , and -3 , platelet-derived growth factor (PDGF)- $\alpha$, PDGF- $\beta$ and $c-k i t$ tyrosine kinases was also evaluated in NPC. ${ }^{69}$ Two (6\%) out of 33 patients enjoyed a partial response and another $16(48 \%)$ patients had stable disease. Treatment was fairly tolerated; fatigue and hand-foot syndrome were the commonest grade $\geq 3$ toxicities. One patient died of epistaxis and myocardial infarction. At around the same time, bevacizumab, an anti-angiogenic monoclonal antibody, was also shown to produce promising responses when combined with cisplatin chemoradiation as the definite treatment for locally advanced NPC. ${ }^{70}$ Whether the effect of bevacizumab and systemic chemotherapy can also accrue in a metastatic setting will depend on results from future studies.

New genes and / or growth factor pathways have been identified as potential targets of new targeted therapies. For instance, the PI3K/Akt pathway was recently revealed to be frequently involved in NPC tumourigenesis and progression..$^{71,72}$ Apart from that, microRNAs (miRNAs), a diverse class of 2024-nucleotide non-coding RNAs were also found upregulated in NPC compared with non-tumorous nasopharyngeal tissues. ${ }^{73-78} \mathrm{~A}$ local study found that upregulation of miRNA-144 promoted malignant progression by repressing the expression of a tumour suppressor gene phosphatase and tensin homologue (PTEN), which is partially responsible for upregulation of the PI3K/Akt pathway in NPC ${ }^{65}$ In-vitro cell-line studies have demonstrated that Akt inhibitors can suppress tumour growth. Hopefully the efficacy of these inhibitors can be further verified in phase II and III clinical trials..$^{79,80}$

\section{CONCLUSION}

In summary, a platinum-based chemotherapy regimen especially cisplatin and 5-FU is still the principal firstline treatment for recurrent / metastatic NPC. Cisplatin is preferred over carboplatin based on its long history with much accumulated experience by oncologists. However, other factors including the toxicity profile of chemotherapy, renal function, and length of stay in hospital for protracted 5-FU infusions should be taken into account when considering this regimen. Newer chemotherapeutic agents like gemcitabine, capecitabine 
and taxanes can be safely combined with platinum compounds either as first-line or subsequent-line therapy to substitute for 5-FU, especially when hospitalisation is a major concern. Combination chemotherapy using three or more agents has not been shown superior to doublet regimens. The role of targeted therapy in NPC is still evolving. New targets and growth factor pathways have been gradually identified and new compounds against these targets are awaited. Current attention is also focused on immunotherapy, using autologous EBV-specific cytotoxic T-lymphocytes (CTLs) targeting the antigens of EBV including EBNA1, latent membrane protein-1 (LMP-1) and latent membrane protein-2 (LMP-2). ${ }^{81,82}$ Previous pilot studies have demonstrated that CTL immunotherapy is well tolerated without any immunosuppressive effects on bone marrow as seen in chemotherapy. ${ }^{83-87}$ One pilot study conducted by Secondino et $\mathrm{al}^{86}$ showed an OR rate of $27 \%$ and disease control rate of $55 \%$ in a series of 11 patients. Preliminary results of using a novel adenoviral vector-based vaccine (AdE1-LMPoly) that encodes multiple CTL epitones from LMP1 and LMP2 are also promising. ${ }^{87}$ With all these novel ideas and treatment options, we anticipate a new paradigm of systemic treatment for metastatic NPC in the near future.

\section{DECLARATION}

No conflicts of interest were declared by the authors.

\section{REFERENCES}

1. Baujat B, Audry H, Bourhis J, Chan AT, Onat H, Chua DT, et al. Chemotherapy in locally advanced nasopharyngeal carcinoma: an individual patient data meta-analysis of eight randomized trials and 1753 patients. Int J Radiat Oncol Biol Phys. 2006;64:47-56. cross ref

2. Lee AW, Sze WM, Au JS, Leung SF, Leung TW, Chua DT, et al. Treatment results for nasopharyngeal carcinoma in the modern era: the Hong Kong experience. Int J Radiat Oncol Biol Phys. 2005;61:1107-16. cross ref

3. Ma BB, Chan AT. Recent perspectives in the role of chemotherapy in the management of advanced nasopharyngeal carcinoma. Cancer. 2005;103:22-31. cross ref

4. Shiu WCT, Tsao SY. Efficacy of 4-epidoxorubicin in advanced nasopharyngeal carcinoma. Clin Trials J. 1989;26:149-52.

5. Dugan M, Choy D, Ngai A, Sham J, Choi P, Shiu W, et al. Multicenter phase II trial of mitoxantrone in patients with advanced nasopharyngeal carcinoma in Southeast Asia: an Asian-Oceanian Clinical Oncology Association Group Study. J Clin Oncol. 1993;11:70-6

6. Au E, Tan EH, Ang PT. Activity of paclitaxel by three-hour infusion in Asian patients with metastatic undifferentiated nasopharyngeal cancer. Ann Oncol. 1998;9:327-9. cross ref

7. Poon D, Chowbay B, Cheung YB, Leong SS, Tan EH. Phase II study of irinotecan (CPT-11) as salvage therapy for advanced nasopharyngeal carcinoma. Cancer. 2005;103:576-81. cross ref

8. Foo KF, Tan EH, Leong SS, Wee JT, Tan T, Fong KW, et al. Gemcitabine in metastatic nasopharyngeal carcinoma of the undifferentiated type. Ann Oncol. 2002;13:150-6. cross ref

9. Ma BB, Tannock IF, Pond GR, Edmonds MR, Siu LL. Chemotherapy with gemcitabine-containing regimens for locally recurrent or metastatic nasopharyngeal carcinoma. Cancer. 2002;95:2516-23. cross ref

10. Chua DT, Sham JS, Au GK. A phase II study of capecitabine in patients with recurrent and metastatic nasopharyngeal carcinoma pretreated with platinum-based chemotherapy. Oral Oncol. 2003;39:361. cross ref

11. Chua D, Wei WI, Sham JS, Au GK. Capecitabine monotherapy for recurrent and metastatic nasopharyngeal cancer. Jpn J Clin Oncol. 2008:38:244-9. cross ref

12. Ciuleanu E, Irimie A, Ciuleanu TE, Popita V, Todor N, Ghilezan $\mathrm{N}$. Capecitabine as salvage treatment in relapsed nasopharyngeal carcinoma: a phase II study. J BUON. 2008;13:37-42.

13. Zhang L, Zhang Y, Huang PY, Xu F, Peng PJ, Guan ZZ. Phase II clinical study of gemcitabine in the treatment of patients with advanced nasopharyngeal carcinoma after the failure of platinum-based chemotherapy. Cancer Chemother Pharmacol. 2008;61:33-8. cross ref

14. Ngeow J, Lim WT, Leong S, Ang MK, Toh CK, Gao F, et al. Docetaxel is effective in heavily pretreated patients with disseminated nasopharyngeal carcinoma. Ann Oncol. 2011;22:71822. cross ref

15. Wang TL, Tan YO. Cisplatin and 5-fluorouracil continuous infusion for metastatic nasopharyngeal carcinoma. Ann Acad Med Singapore. 1991;20:601-3.

16. Au E, Ang PT. A phase II trial of 5-fluorouracil and cisplatinum in recurrent or metastatic nasopharyngeal carcinoma. Ann Oncol. 1994;5:87-9.

17. Chi KH, Chan WK, Cooper DL, Yen SH, Lin CZ, Chen KY. A phase II study of outpatient chemotherapy with cisplatin, 5-fluorouracil and leucovorin in nasopharyngeal carcinoma. Cancer. 1994;73:247-52.

18. Stein ME, Ruff P, Weaving A, Fried J, Bezwoda WR. A phase II study of cisplatin/ifosfamide in recurrent/metastatic undifferentiated nasopharyngeal carcinoma among young blacks in southern Africa. Am J Clin Oncol. 1996;19:386-8. cross ref

19. Yeo W, Leung TW, Leung SF, Teo PM, Chan AT, Lee WY, et al. Phase II study of the combination of carboplatin and 5-fluorouracil in metastatic nasopharyngeal carcinoma. Cancer Chemother Pharmacol. 1996;38:466-70. cross ref

20. Yeo W, Leung TW, Chan AT, Chiu SK, Yu P, Mok TS, et al. A phase II study combination of paclitaxel and carboplatin in advanced nasopharyngeal carcinoma. Eur J Cancer. 1998;34:202731. cross ref

21. Tan EH, Khoo KS, Wee J, Fong KW, Lee KS, Lee KM, et al. Phase II trial of a paclitaxel and carboplatin combination in Asian patients with metastatic nasopharyngeal carcinoma. Ann Oncol. 1999;10:235-7. cross ref

22. Ciuleanu TE, Fountzilas G, Ciuleanu E, Plataniotis M, Todor N, Ghilezan N. Paclitaxel and carboplatin in relapsed or metastatic nasopharyngeal carcinoma: a multicenter phase II study. J BUON. 2004:9:161-5.

23. Ngan RK, Yiu HH, Lau WH, Yau S, Cheung FY, Chan TM, et al. Combination gemcitabine and cisplatin chemotherapy for metastatic or recurrent nasopharyngeal carcinoma: report of a phase II study. Ann Oncol. 2002;13:1252-8. cross ref

24. Wang J, Li J, Hong X, Tang W, Hu X, Wang B, et al. Retrospective case series of gemcitabine plus cisplatin in the treatment of recurrent and metastatic nasopharyngeal carcinoma. Oral Oncol. 2008;44:464-70. cross ref

25. Ma BB, Hui EP, Wong SC, Tung SY, Yuen KK, King A, et al. Multicenter phase II study of gemcitabine and oxaliplatin in advanced nasopharyngeal carcinoma - correlation with excision 
repair cross-complementing-1 polymorphisms. Ann Oncol. 2009;20:1854-9. cross ref

26. McCarthy JS, Tannock IF, Degendorfer P, Panzarella T, Furlan M, Siu LL. A Phase II trial of docetaxel and cisplatin in patients with recurrent or metastatic nasopharyngeal carcinoma. Oral Oncol. 2002;38:686-90. cross ref

27. Chua DT, Sham JS, Au GK. A phase II study of docetaxel and cisplatin as first-line chemotherapy in patients with metastatic nasopharyngeal carcinoma. Oral Oncol. 2005;41:589-95. cross ref

28. Li YH, Wang FH, Jiang WQ, Xiang XJ, Deng YM, Hu GQ, et al. Phase II study of capecitabine and cisplatin combination as first-line chemotherapy in Chinese patients with metastatic nasopharyngeal carcinoma. Cancer Chemother Pharmacol. 2008;62:539-44. cross ref

29. Chua DT, Kwong DL, Sham JS, Au GK, Choy D. A phase II study of ifosfamide, 5-fluorouracil and leucovorin in patients with recurrent nasopharyngeal carcinoma previously treated with platinum chemotherapy. Eur J Cancer. 2000;36:736-41 . cross ref

30. Huang HQ, Zhou ZM, Li YH, Jiang WQ, He YJ, Teng XY, et al. Preliminary results of ifosfamide and doxorubicin regimen in treatment of patients with recurrent and metastatic nasopharyngeal carcinoma [in Chinese]. Ai Zheng. 2002;21:409-11.

31. Altundag K, Aksoy S, Gullu I, Altundag O, Ozyar E, Yalcin S, et al. Salvage ifosfamide doxorubicin chemotherapy in patients with recurrent nasopharyngeal carcinoma pretreated with Cisplatinbased chemotherapy. Med Oncol. 2004;21:211-5. cross ref

32. Wang CC, Chang JY, Liu TW, Lin CY, Yu YC, Hong RL. Phase II study of gemcitabine plus vinorelbine in the treatment of cisplatinresistant nasopharyngeal carcinoma. Head Neck. 2006;28:7480. cross ref

33. Dede DS, Aksoy S, Cengiz M, Gullu I, Altundag K. Ifosfamide and doxorubicin combination chemotherapy for recurrent nasopharyngeal carcinoma patients. Asian Pac J Cancer Prev. 2012;13:2225-8. cross ref

34. Chen C, Wang FH, Wang ZQ, An X, Luo HY, Zhang L, et al. Salvage gemcitabine-vinorelbine chemotherapy in patients with metastatic nasopharyngeal carcinoma pretreated with platinumbased chemotherapy. Oral Oncol. 2012;48:1146-51. cross ref

35. Yau TK, Shum T, Lee AW, Yeung MW, Ng WT, Chan L. A phase II study of pemetrexed combined with cisplatin in patients with recurrent or metastatic nasopharyngeal carcinoma. Oral Oncol. 2012;48:441-4. cross ref

36. Chua DT, Yiu HH, Seetalarom K, Ng AW, Kurnianda J, Shotelersuk K, et al. Phase II trial of capecitabine plus cisplatin as first-line therapy in patients with metastatic nasopharyngeal cancer. Head Neck. 2012;34:1225-30. cross ref

37. Lokich J, Anderson N. Carboplatin versus cisplatin in solid tumours: an analysis of the literature. Ann Oncol. 1998;9:1321. cross ref

38. Forastiere AA, Metch B, Schuller DE, Ensley JF, Hutchins LF, Triozzi P, et al. Randomized comparison of cisplatin plus fluorouracil and carboplatin plux fluorouracil versus methotrexate in advanced squamous-cell carcinoma of the head and neck: a Southwest Oncology Group Study. J Clin Oncol. 1992;10:1245-51.

39. De Andrés L, Brunet J, López-Pousa A, Burgués J, Vega M, Tabernero JM, et al. Randomized trial of neoadjuvant cisplatin and fluorouracil versus carboplatin and fluorouracil in patients with stage IV-M0 head and neck cancer. J Clin Oncol. 1995;13:1493500 .

40. Chitapanarux I, Lorvidhaya V, Kamnerdsupaphon P, Sumitsawan Y, Tharavichitkul E, Sukthomya V, et al. Chemoradiation comparing cisplatin versus carboplatin in locally advanced nasopharyngeal cancer: randomised, non-inferiority, open trial. Eur J Cancer. 2007;43:1399-406. cross ref

41. Kua VF, Ismail F, Chee Ee Phua V, Aslan NM. Carboplatin/5fluorouracil as an alternative to Cisplatin/5- fluorouracil for metastatic and recurrent head and neck squamous cell carcinoma and nasopharyngeal carcinoma. Asian Pac J Cancer Prev. 2013;14:1121-6. cross ref

42. Chan AT, Gregoire V, Lefebvre JL, et al. Nasopharyngeal cancer: EHNS-ESMO-ESTRO Clinical Practice Guidelines for diagnosis, treatment and follow-up. Ann Oncol. 2010;21 Suppl 5:v1879. cross ref

43. Lee HW, Hwang YH, Han JH, Choi JH, Kang SY, Jeong SH, et al. High expression of excision repair cross-complementation group 1 protein predicts poor outcome in patients with nasopharyngeal cancer. Oral Oncol. 2010;46:209-13. cross ref

44. Huang PY, Li Y, Mai HQ, Luo RZ, Cai YC, Zhang L. Expression of ERCC1 predicts clinical outcome in locoregionally advanced nasopharyngeal carcinoma treated with cisplatin-based induction chemotherapy. Oral Oncol. 2012;48:964-8. cross ref

45. Sun JM, Ahn MJ, Park MJ, Lee HY, Ahn JS, Lee S, et al. Expression of excision repair cross-complementation group 1 as predictive marker for nasopharyngeal cancer treated with concurrent chemoradiotherapy. Int J Radiat Oncol Biol Phys. 2011;80:655-60. cross ref

46. Chen C, Wang F, Wang Z, Li C, Luo H, Liang Y, et al. Polymorphisms in ERCC1 C8092A predict progression-free survival in metastatic/recurrent nasopharyngeal carcinoma treated with cisplatin-based chemotherapy. Cancer Chemother Pharmacol. 2013;72:315-22. cross ref

47. Chan SH, Cheung FM, Ng WT, Choi CW, Cheung KN, Yiu $\mathrm{KH}$, et al. Can the analysis of ERCC1 expression contribute to individualized therapy in nasopharyngeal carcinoma? Int J Radiat Oncol Biol Phys. 2011;79:1414-20. cross ref

48. Jagdis A, Phan T, Klimowicz AC, Laskin JJ, Lau HY, Petrillo SK, et al. Assessment of ERCC1 and XPF protein expression using quantitative immunohistochemistry in nasopharyngeal carcinoma patients undergoing curative intent treatment. Int J Radiat Oncol Biol Phys. 2013;85:1340-5. cross ref

49. Boussen H, Cvitkovic E, Wendling JL, Bachouchi M, Mahjoubi R, et al. Chemotherapy of metastatic and/or recurrent undifferentiated nasopharyngeal carcinoma with cisplatin, bleomycin and fluorouracil. J Clin Oncol. 1991;9:1675-81.

50. Su WC, Chen TY, Kao RH, Tsao CJ. Chemotherapy with cisplatin and continuous infusion of 5-fluorouracil and bleomycin for recurrent and metastatic nasopharyngeal carcinoma in Taiwan. Oncology. 1993;50:205-8. cross ref

51. Azli N, Fandi A, Bachouchi M, Rahal M, Lianes P, Wibault P, et al. Final report of a phase II study of chemotherapy with bleomycin, epirubicin, and cisplatin for locally advanced and metastatic/ recurrent undifferentiated carcinoma of the nasopharyngeal type. Cancer J Sci Am. 1995;1:222-9.

52. Siu LL, Czaykowshi PM, Tannock IF. Phase I/II study of the CAPABLE regimen for patients with poorly differentiated carcinoma of the nasopharynx. J Clin Oncol. 1998;16:2514-21.

53. Taamma A, Fandi A, Azli N, Wibault P, Chouaki N, Hasbini A, et al. Phase II trial of chemotherapy with 5-fluorouracil, bleomycin, epirubicin, and cisplatin for patients with locally advanced, metastatic, or recurrent undifferentiated carcinoma of the nasopharyngeal type. Cancer. 1999;86:1101-8. cross ref

54. Hasbini A, Mahjoubi R, Fandi A, Chouaki N, Taamma A, Lianes $\mathrm{P}$, et al. Phase II trial combining mitomycin with 5-fluorouracil, epirubicin, and cisplatin in recurrent and metastatic undifferentiated carcinoma of nasopharyngeal type. Ann Oncol. 1999;10:4215. cross ref

55. Leong SS, Wee J, Rajan S, Toh CK, Lim WT, Hee SW, et al. Triplet combination of gemcitabine, paclitaxel, and carboplatin followed by maintenance 5 -fluorouracil and folinic acid in patients with metastatic nasopharyngeal carcinoma. Cancer. 2008;113:13327. cross ref 
56. Huang HQ, Cai QQ, Lin XB, Wang AL, Bu Q, Hu XH, et al. Preliminary result of multicenter clinical trial on the docetaxel, 5-Fu and DDP in the treatment of advanced, recurrent or metastatic nasopharyngeal carcinoma [in Chinese]. Zhonghua Zhong Liu Za Zhi. 2008;30:314-6.

57. Fujii M, Yamashita T, Ishiguro R, Tashiro M, Kameyama K. Significance of epidermal growth factor receptor and tumor associated tissue eosinophilia in the prognosis of patients with nasopharyngeal carcinoma. Auris Nasus Larynx. 2002;29:17581. cross ref

58. Sheen TS, Huang YT, Chang YL, Ko JY, Wu CS, Yu YC, et al. Epstein-Barr virus-encoded latent membrane protein 1 coexpresses with epidermal growth factor receptor in nasopharyngeal carcinoma. Jpn J Cancer Res. 1999;90:1285-92. cross ref

59. Leong JL, Loh KS, Putti TC, Goh BC, Tan LK. Epidermal growth factor receptor in undifferentiated carcinoma of the nasopharynx. Laryngoscope. 2004;114:153-7. cross ref

60. Chua DT, Wei WI, Wong MP, Sham JS, Nicholls J, Au GK. Phase II study of gefitinib for the treatment of recurrent and metastatic nasopharyngeal carcinoma. Head Neck. 2008;30:863-7. cross ref

61. Ma B, Hui EP, King A, To KF, Mo F, Leung SF, et al. A phase II study of patients with metastatic or locoregionally recurrent nasopharyngeal carcinoma and evaluation of plasma EpsteinBarr virus DNA as a biomarker of efficacy. Cancer Chemother Pharmacol. 2008;62:59-64. cross ref

62. You B, Le Tourneau C, Chen EX, Wang L, Jarvi A, Bharadwaj $\mathrm{RR}$, et al. A Phase II trial of erlotinib as maintenance treatment after gemcitabine plus platinum-based chemotherapy in patients with recurrent and/or metastatic nasopharyngeal carcinoma. Am J Clin Oncol. 2012;35:255-60. cross ref

63. Chan AT, Hsu MM, Goh BC, Hui EP, Liu TW, Millward MJ, et al. Phase II study of cetuximab in combination with carboplatin in patients with recurrent or metastatic nasopharyngeal carcinoma. J Clin Oncol. 2005;23:3568-76. cross ref

64. Hui EP, Chan AT, Pezzella F, Turley H, To KF, Poon TC, et al. Coexpression of hypoxia-inducible factors 1 alpha and 2alpha, carbonic anhydrase IX, and vascular endothelial growth factor in nasopharyngeal carcinoma and relationship to survival. Clin Cancer Res. 2002;8:2595-604.

65. Krishna SM, James S, Balaram P. Expression of VEGF as prognosticator in primary nasopharyngeal cancer and its relation to EBV status. Virus Res. 2006; 115:85-90. cross ref

66. Elser C, Siu LL, Winquist E, Agulnik M, Pond GR, Chin SF, et al. Phase II trial of sorafenib in patients with recurrent or metastatic squamous cell carcinoma of the head and neck or nasopharyngeal carcinoma. J Clin Oncol. 2007;25:3766-73. cross ref

67. Xue C, Huang Y, Huang PY, Yu QT, Pan JJ, Liu LZ, et al. Phase II study of sorafenib in combination with cisplatin and 5-fluorouracil to treat recurrent or metastatic nasopharyngeal carcinoma. Ann Oncol. 2013;24:1055-61. cross ref

68. Hui EP, Ma BBY, King AD, Mo F, Chan SL, Kam MK, et al. Haemorrhagic complications in a phase II study of sunitinib in patients of nasopharyngeal carcinoma who has previously received high-dose radiation. Ann Oncol. 2011;22:1280-7. cross ref

69. Lim WT, Ng QS, Ivy P, Leong SS, Singh O, Chowbay B, et al. A phase II study of pazopanib in Asian patients with recurrent/ metastatic nasopharyngeal carcinoma. Clin Cancer Res. 2011;17:5481-9. cross ref

70. Lee NY, Zhang Q, Pfister DG, Kim J, Garden AS, Mechalakos $\mathrm{J}$, et al. Addition of bevacizumab to standard chemoradiation for locoregionally advanced nasopharyngeal carcinoma (RTOG 0615): a phase 2 multi-institutional trial. Lancet Oncol. 2012;23:17280. cross ref

71. Xu X, Yang H, Huo X. Expression and significance of PTEN in nasopharyngeal carcinoma [in Chinese]. Lin Chuang Er Bi Yan Hou Ke Za Zhi. 2004;18:658-9.

72. Pedrero JM, Carracedo DG, Pinto CM, Zapatero AH, Rodrigo JP, Nieto CS, et al. Frequent genetic and biochemical alterations of the PI3-K/AKT/PTEN pathway in head and neck squamous cell carcinoma. Int J Cancer. 2005; 114:242-8. cross ref

73. Sengupta S, den Bonn JA, Chen IH, Newton MA, Stanhope SA, Cheng YJ, et al. MicroRNA 29c is down-regulated in nasopharyngeal carcinomas, up-regulating mRNAs encoding extracellular matrix proteins. Proc Natl Acad Sci USA. 2008;105:5874-8. cross ref

74. Xia H, Ng SS, Jiang S, Cheung WK, Sze J, Bian XW, et al. miR-200a-mediated downregulation of ZEB 2 and CTNNB 1 differentially inhibits nasopharyngeal carcinoma cell growth, migration and invasion. Biochem Biophys Res Commun. 2010;391:535-41. cross ref

75. Shi W, Alajez NM, Bastianutto C, Hui AB, Mocanu JD, Ito E, et al. Significance of Plk1 regulation by miR-100 in human nasopharyngeal cancer. Int J Cancer. 2010;126:2036-48.

76. Zhang L, Deng T, Li X, Liu H, Zhou H, Ma J, et al. microRNA-141 is involved in a nasopharyngeal carcinoma-related genes network. Carcinogenesis. 2010;31:559-66. cross ref

77. Choy EY, Siu KL, Kok KH, Lung RW, Tsang CM, To KF, et al. An Epstein-Barr virus-encoded microRNA targets PUMA to promote host cell survival. J Exp Med. 2008;205:2551-60. cross ref

78. Zhang LY, Lee VHF, Wong AM, Kwong DL, Zhu YH, Dong SS, et al. MicroRNA-144 promotes cell proliferation, migration and invasion in nasopharyngeal carcinoma through repression of PTEN. Carcinogenesis. 2013;34:454-63. cross ref

79. Lo MC, Yip TC, Ngan KC, Cheng WW, Law CK, Chan PS, et al. Role of MIF/CXCL8/CXCR2 signaling in the growth of nasopharyngeal carcinoma tumor spheres. Cancer Lett. 2013;335:81-92. cross ref

80. Ma BB, Lui VW, Hui CW, Lau CP, Wong CH, Hui EP, et al. Preclinical evaluation of the AKT inhibitor MK-2206 in nasopharyngeal carcinoma cell lines. Invest New Drugs. 2013;31:567-75. cross ref

81. Williams H, Crawford DH. Epstein-Barr virus: the impact of scientific advances on clinical practice. Blood. 2006;107:8629. cross ref

82. Basso S, Zecca M, Merli P, Gurrado A, Secondino S, Quartuccio $\mathrm{G}$, et al. T cell therapy for nasopharyngeal carcinoma. J Cancer. 2011;2:341-6.

83. Chua D, Huang J, Zheng B, Lau SY, Luk W, Kwong DL, et al. Adoptive transfer of autologous Epstein-Barr virus-specific cytotoxic $\mathrm{T}$ cells for nasopharyngeal carcinoma. Int J Cancer. 2001;94:73-80. cross ref

84. Louis CU, Straathof K, Bollard CM, Ennamuri S, Gerken C, Lopez TT, et al. Adoptive transfer of EBV-specific T cells results in sustained clinical responses in patients with locoregional nasopharyngeal carcinoma. J Immunother. 2010;33:983-90. cross ref

85. Louis CU, Straathof K, Bollard CM, Gerken C, Huls MH, Gresik MV, et al. Enhancing the in vivo expansion of adoptively transferred EBV-specific CTL with lymphodepleting CD45 monoclonal antibodies in NPC patients. Blood. 2009;113:244250. cross ref

86. Secondino S, Zecca M, Licitra L, Gurrado A, Schiavetto I, Bossi P, et al. T-cell therapy for EBV-associated nasopharyngeal carcinoma: preparative lymphodepleting chemotherapy does not improve clinical results. Ann Oncol. 2012;23:435-41. cross ref

87. Smith C, Tsang J, Beagley L, Chua D, Lee V, Li V, et al. Effective treatment of metastatic forms of Epstein-Barr virus-associated nasopharyngeal carcinoma with a novel adenovirus-based adoptive immunotherapy. Cancer Res. 2012;72:1116-25. cross ref 